\title{
Nitrate improves ammonia incorporation into rumen microbial protein in lactating dairy cows fed a low-protein diet
}

\author{
Rong Wang, ${ }^{*} \dagger$ Min Wang, ${ }^{*} \ddagger^{1}$ Emilio M. Ungerfeld,§ Xiu Min Zhang, ${ }^{*}$ Dong Lei Long, ${ }^{*} \dagger$ Hong Xiang Mao, ${ }^{*} \dagger$ \\ Jin Ping Deng,† André Bannink,\# and Zhi Liang Tan*¥ \\ ${ }^{*}$ CAS Key Laboratory for Agro-Ecological Processes in Subtropical Region, National Engineering Laboratory for Pollution Control \\ and Waste Utilization in Livestock and Poultry Production, Institute of Subtropical Agriculture, The Chinese Academy of Sciences, \\ Changsha, Hunan 410125, P. R. China \\ †Department of Animal Science and Technology, University of Hunan Agricultural University, Changsha 410128, P. R. China \\ łHunan Co-Innovation Center of Animal Production Safety, Changsha, Hunan 410128, P. R. China \\ §Instituto de Investigaciones Agropecuarias INIA Carillanca, 8340422 Temuco, Chile \\ \#Wageningen Livestock Research, Wageningen University \& Research, De Elst 1, 6708 WD Wageningen, the Netherlands
}

\begin{abstract}
Generation of ammonia from nitrate reduction is slower compared with urea hydrolysis and may be more efficiently incorporated into ruminal microbial protein. We hypothesized that nitrate supplementation could increase ammonia incorporation into microbial protein in the rumen compared with urea supplementation of a low-protein diet fed to lactating dairy cows. Eight multiparous Chinese Holstein dairy cows were used in a crossover design to investigate the effect of nitrate or an isonitrogenous urea inclusion in the basal lowprotein diet on rumen fermentation, milk yield, and ruminal microbial community in dairy cows fed a low-protein diet in comparison with an isonitrogenous urea control. Eight lactating cows were blocked in 4 pairs according to days in milk, parity, and milk yield and allocated to urea $(7.0 \mathrm{~g}$ urea $/ \mathrm{kg}$ of dry matter of basal diet) or nitrate (14.6 g of $\mathrm{NO}_{3}^{-} / \mathrm{kg}$ of dry matter of basal diet, supplemented as sodium nitrate) treatments, which were formulated on $75 \%$ of metabolizable protein requirements. Nitrate supplementation decreased ammonia concentration in the rumen liquids $(-33.1 \%)$ and plasma $(-30.6 \%)$ as well as methane emissions $(-15.0 \%)$ and increased dissolved hydrogen concentration (102\%), microbial N (22.8\%), propionate molar percentage, milk yield, and $16 \mathrm{~S}$ rRNA gene copies of Selenomonas ruminantium. Ruminal dissolved hydrogen was positively correlated with the molar proportion of propionate $(\mathrm{r}=0.57)$, and negatively correlated with acetate-to-propionate ratio $(\mathrm{r}=-0.57)$ and estimated net metabolic hydrogen production relative to total VFA produced $(\mathrm{r}=-0.58)$. Nitrate reduction
\end{abstract}

\footnotetext{
Received April 10, 2018.

Accepted July 11, 2018.

${ }^{1}$ Corresponding author: mwang@isa.ac.cn
}

to ammonia redirected metabolic hydrogen away from methanogenesis, enhanced ammonia incorporation into rumen microbial protein, and shifted fermentation from acetate to propionate, along with increasing $S$. ruminantium 16S rRNA gene copies, likely leading to the increased milk yield.

Key words: nitrate, dissolved hydrogen, rumen fermentation, microbial protein

\section{INTRODUCTION}

Molecular hydrogen $\left(\mathrm{H}_{2}\right)$ is produced from metabolic hydrogen $([\mathrm{H}])$ during carbohydrate fermentation in the rumen and then used by methanogens to produce methane (Hungate, 1967), which is a potent greenhouse gas (Reisinger and Clark, 2018) and represents a loss of between 2 and $12 \%$ of ingested gross energy in ruminants (Johnson and Johnson, 1995). Redirecting [H] from methanogenesis to alternative fermentation endproducts could have potential nutritional benefits to ruminants. Nitrate $\left(\mathrm{NO}_{3}{ }^{-}\right)$is a strong inorganic anion with a high redox potential. In the rumen, nitrate is first reduced to nitrite $\left(\mathrm{NO}_{2}{ }^{-} ; \mathrm{NO}_{3}{ }^{-}+[2 \mathrm{H}] \rightarrow \mathrm{NO}_{2}{ }^{-}+\right.$ $\left.\mathrm{H}_{2} \mathrm{O}\right)$, and then further reduced to ammonia $\left(\mathrm{NO}_{2}{ }^{-}+\right.$ $3[2 \mathrm{H}]+2 \mathrm{H}^{+} \rightarrow \mathrm{NH}_{4}{ }^{+}+2 \mathrm{H}_{2} \mathrm{O}$; Latham et al., 2016). Nitrate reduction to ammonia is energetically more favorable [Gibbs energy changes $\left(\Delta \mathbf{G}^{0}\right)=-599.6 \mathrm{~kJ} /$ mol] than the reduction of carbon dioxide to methane $\left(\Delta \mathrm{G}^{0}=-131 \mathrm{~kJ} / \mathrm{mol}\right.$; Latham et al., 2016). Ammonia resulting from nitrate reduction can be incorporated into carbon skeletons to form microbial AA and protein. Nutritionally, microbial protein is the most important, and the most economical, source of AA for ruminants (Hristov and Broderick, 1996).

Previous studies have reported that nitrate supplementation decreased methane production in ruminants in comparison to isonitrogenous urea supplementation 
(van Zijderveld et al., 2010; Guyader et al., 2015; Troy et al., 2015); however, replacement of urea with nitrate has not benefited the productivity of cattle (Lee and Beauchemin, 2014; Troy et al., 2015). It is thought that for diets sufficient in $\mathrm{N}$, additional ammonia formed from nitrate reduction may not be nutritionally beneficial (Olijhoek et al., 2016). The lack of benefit may also be affected by other factors, such as the rate of dietary carbohydrate degradation being synchronized with $\mathrm{N}$ release in the rumen (Sinclair et al., 1993). The generation of ammonia from nitrate reduction is slower than urea hydrolysis (Marais et al., 1988; Lee et al., 2017), which may benefit ammonia incorporation into carbon skeletons to form microbial AA (Nolan et al., 2010; Li et al., 2012). Herein, we hypothesized that nitrate supplementation could increase ammonia incorporation into microbial protein in the rumen, which might exert a nutritional benefit to rumen function, and hence productivity of lactating dairy cows fed a low-protein diet, and lead to an improvement in the productivity. To test this hypothesis, we replaced dietary urea with nitrate in lactating dairy cows fed low-protein diets and then measured nutrient digestibility, milk yield, methane emissions, blood metabolites, ruminal fermentation, and selected groups of microorganisms in the rumen.

\section{MATERIALS AND METHODS}

\section{Experimental Methods}

All procedures involving animals were approved by the Animal Care Committee, Institute of Subtropical Agriculture, the Chinese Academy of Sciences, Changsha, China.

\section{Experimental Design and Animals}

Eight Chinese Holstein dairy cows $(200 \pm 10$ DIM; parity $=2.56 \pm 0.88$; milk yield $=15.9 \pm 0.86 \mathrm{~kg} / \mathrm{d}$; $\mathrm{BW}=508 \pm 20.2 \mathrm{~kg}$; mean $\pm \mathrm{SD}$ ) were blocked in 4 pairs according to DIM, parity, and milk yield. Within a pair, cows were randomly allocated to 1 of 2 treatments, with either urea (control) or sodium nitrate $\left(\mathrm{NaNO}_{3}\right.$, Hunan Huihong Reagent Co. Ltd., Changsha, China) as an $\mathrm{N}$ supplement. The study consisted of 2 consecutive experimental periods in a crossover design. Each period consisted of $20 \mathrm{~d}$ of adaptation to the diets and $15 \mathrm{~d}$ of sampling and data collection. The $15 \mathrm{~d}$ of sampling and data collection included $5 \mathrm{~d}$ for total fecal sample collection, $8 \mathrm{~d}$ for measurements of methane emissions ( $2 \mathrm{~d}$ for each of 4 cows), and $2 \mathrm{~d}$ for collection of rumen fluid and blood at 2.5 and $6 \mathrm{~h}$ after fresh feed offered in the morning. We further randomly separated the 4 cows of each treatment into 4 groups of 2 cows each on different treatments, which were staggered by $8 \mathrm{~d}$ in the application of the treatments.

\section{Diet and Feeding}

The diets were supplied by a basal diet (Table 1) and supplementation of urea or nitrate and formulated to deliver $75 \%$ of MP requirements according to the software of Cornell-Penn-Miner Dairy System (CPMDairy; Boston et al., 2000). The basal diet contained $87.9 \mathrm{~g}$ of $\mathrm{CP} / \mathrm{kg}$ of DM. Urea $(7.0 \mathrm{~g}$ of urea $/ \mathrm{kg}$ of $\mathrm{DM}$ of basal diet) or sodium nitrate $\left(14.6 \mathrm{~g}\right.$ of $\mathrm{NO}_{3}^{-} / \mathrm{kg}$ of DM of basal diet), which equals $20.9 \mathrm{~g}$ of $\mathrm{CP} / \mathrm{kg}$ of DM of basal diet, were added to the basal diet for urea or nitrate treatment, respectively. During each period, both urea and nitrate were gradually introduced in the diet at incremental portions of $25 \%$ from d 2 to 5 until $100 \%$ of the experimental dose was fed at $\mathrm{d} 6$.

Cows were housed in a tiestall barn, fed individually at 0530 and $1500 \mathrm{~h}$, and milked twice daily at 0630 and $1600 \mathrm{~h}$; individual milk yields were recorded. All cows had free access to fresh water. Diets were offered ad libitum during the first $7 \mathrm{~d}$ of each period to let the cows

Table 1. Ingredient and chemical composition ( $\mathrm{g} / \mathrm{kg}$ of DM) of basal diet

\begin{tabular}{lc}
\hline Item & Basal diet \\
\hline Ingredient (g/kg of DM) & \\
Grass silage & 520 \\
Corn grain & 272 \\
Soybean meal & 50 \\
Wheat middlings & 10 \\
Wheat bran & 80 \\
Oil & 40 \\
Sodium chloride & 5.0 \\
Calcium carbonate & 8.0 \\
Calcium bicarbonate & 5.0 \\
Premix & 10 \\
Chemical composition ${ }^{3}$ (g/kg of DM) & \\
OM & 880 \\
CP & 87.9 \\
Starch & 278 \\
Forage NDF & 295 \\
NDF & 426 \\
ADF & 210 \\
NDF/Starch & 1.48 \\
NE ${ }_{\mathrm{L}}^{4}$ (Mcal/kg of DM) & 1.49 \\
ME $^{4}$ (Mcal/kg of DM) & 2.31 \\
MP $^{4}$ (g/kg of DM) & 71.3 \\
\hline
\end{tabular}

${ }^{1}$ The grass silage contained $24.7 \% \mathrm{DM}$, and $932 \mathrm{~g} / \mathrm{kg}$ of OM, $58.9 \mathrm{~g} /$ $\mathrm{kg}$ of CP, $65.6 \mathrm{~g} / \mathrm{kg}$ of starch, $591 \mathrm{~g} / \mathrm{kg}$ of NDF, and $376 \mathrm{~g} / \mathrm{kg}$ of ADF on a DM basis.

${ }^{2}$ The premix (vitamins and microelements) provided (per kilogram of DM) 1,000,000 IU of vitamin A, 200,000 IU of vitamin D, 1,250 IU of vitamin E, 8,000 $\mathrm{mg}$ of $\mathrm{Zn}, 80 \mathrm{mg}$ of Se, $120 \mathrm{mg}$ of I, 2,000 $\mathrm{mg}$ of Fe, $40 \mathrm{mg}$ of $\mathrm{Co}, 2,500 \mathrm{mg}$ of $\mathrm{Mn}$, and 2,000 $\mathrm{mg}$ of $\mathrm{Cu}$.

${ }^{3}$ Mean values from the analysis of 3 samples.

${ }^{4}$ Calculated based on Cornell-Penn-Miner Dairy System (CPM-Dairy; Boston et al., 2000). 
adapt to the treatment diets and measure individual feed intake. From d 8 to 35, DMI within a block was restricted to $95 \%$ of the ad libitum DMI of the animal to avoid diet selection. Feed refusals, if present, were collected and analyzed to determine the actual nutrient intake.

\section{Nutrient Digestibility and Milk Yield}

Nutrient digestibility was measured for $5 \mathrm{~d}$. Total feces were collected, weighed, and mixed daily. A subsample $(\sim 1 \%)$ was frozen immediately at $-20^{\circ} \mathrm{C}$ and another subsample $(\sim 1 \%)$ was acidified using $10 \%$ (wt/ wt) $\mathrm{H}_{2} \mathrm{SO}_{4}$ to prevent $\mathrm{N}$ loss and then frozen immediately at $-20^{\circ} \mathrm{C}$. Fecal samples were dried at $65^{\circ} \mathrm{C}$ for $48 \mathrm{~h}$ in a forced-air oven and ground through a 1-mm screen. The acidified oven-dried samples were used for total $\mathrm{N}$ analysis, whereas nonacidified oven-dried samples were used for the rest of chemical analyses.

\section{Methane and Carbon Dioxide Production}

For each cow, methane emissions were measured for 48 $\mathrm{h}$ in a respiration chamber using the protocol by Wang et al. (2015) slightly modified. Each block of 2 cows containing 1 cow of each treatment was passed sequentially through the chamber, and within each block 1 cow passed at a time. Thus, the 8 cows were passed through the chamber during $16 \mathrm{~d}$ ( $8 \mathrm{~d}$ of measurement plus $8 \mathrm{~d}$ in which each group of 2 blocks of cows was staggered). Airflow was maintained under negative chamber pressure (flow rate $=190 \pm 2 \mathrm{~m}^{3} / \mathrm{h}$ ), controlled by the air pump. The mean ambient temperature in the chamber was $17 \pm 2^{\circ} \mathrm{C}$. The outlet gases from the chamber and ambient gas were connected to a multiport inlet unit of the gas analyzer (GGA-30p, Los Gatos Research, San Jose, CA) using 1/8-inch (3.18 mm) polyurethane tubing. Methane concentration was measured and recorded every $30 \mathrm{~min}$. Staff entered each chamber twice daily at 0530 and $1500 \mathrm{~h}$ for approximately $20 \mathrm{~min}$ for feeding and milking. Within the chamber, cows were restrained with free access to the bin and drinking water.

\section{Rumen and Blood Sampling}

Rumen and blood sampling were performed at 2.5 and $6 \mathrm{~h}$ after morning feeding for consecutive $2 \mathrm{~d}$. Rumen contents were collected by oral stomach tubing according to the method described by Wang et al. (2016a). Briefly, samples of rumen contents were collected by inserting an oral stomach tube (Anscitech Co. Ltd., Wuhan, China) to a depth of about $180 \mathrm{~cm}$, so that the probe head could reach the central rumen. Rumen content was collected in a bottle, which was placed on the ground. A suction pump was applied for a few seconds to free any blockage and facilitate the collection of rumen samples, if rumen contents did not automatically flow out. The first initial $>150 \mathrm{~mL}$ of rumen contents were discarded to avoid saliva contamination, and the second $>300 \mathrm{~mL}$ of rumen contents were used for subsequent measurement. One subsample (100 $\mathrm{mL}$ ) was immediately frozen at $-80^{\circ} \mathrm{C}$ for DNA extraction and subsequent quantification of microbial groups. Two other subsamples (35 mL each) were immediately transferred into $50-\mathrm{mL}$ plastic syringes for measuring dissolved $\mathrm{H}_{2}\left(\mathbf{d H}_{2}\right)$ and dissolved methane $\left(\mathbf{d C H}_{4}\right)$ concentration. About $20 \mathrm{~mL}$ of rumen content was used for immediate measurement of rumen $\mathrm{pH}$ using a portable pH meter (Starter 300; Ohaus Instruments Co. Ltd., Shanghai, China). Samples of $2 \mathrm{~mL}$ of rumen fluid were centrifuged at $12,000 \times g$ for $10 \mathrm{~min}$ at $4^{\circ} \mathrm{C}$. Aliquots of the supernatants $(1.5 \mathrm{~mL})$ were transferred into plastic tubes each containing $0.15 \mathrm{~mL}$ of $25 \%$ (wt/vol) metaphosphoric acid and stored at $-20^{\circ} \mathrm{C}$ overnight. Frozen rumen fluid samples were thawed and centrifuged at $12,000 \times g$ for $10 \mathrm{~min}$ at $4^{\circ} \mathrm{C}$ and the supernatants were used for subsequent analysis of ammonia concentration and VFA profile. The remaining samples $(50 \mathrm{~mL})$ were stored at $-20^{\circ} \mathrm{C}$ for determination of concentrations of nitrate, nitrite, and lactate.

Blood samples were obtained from the tail vein using sodium heparinized 5-mL Vacutainer tubes (Shan Dong Ao Sai Te Medical Devices Co. Ltd., Shandong, China). All tubes, for plasma, were kept on ice or in the refrigerator before being centrifuged at $3,500 \times g$ at $4^{\circ} \mathrm{C}$ for $10 \mathrm{~min}$. About $1.5 \mathrm{~mL}$ of supernatant was collected and stored at $-20^{\circ} \mathrm{C}$ for subsequent analyses.

\section{Sample Analysis}

All samples of feeds, refusals, and feces were dried and ground to pass through a 1-mm sieve and analyzed for DM $\left(105^{\circ} \mathrm{C}, 24 \mathrm{~h}\right)$. Ash was determined in a muffle furnace at $550^{\circ} \mathrm{C}$ for $8 \mathrm{~h}$. Organic matter was calculated by difference between DM and ash content. Crude protein $(\mathrm{N} \times 6.25)$ was analyzed using the Kjeldahl method (AOAC International, 2000). Gross energy content was determined using an isothermal automatic calorimeter (5E-AC8018, Changsha Kaiyuan Instruments Co. Ltd., Changsa, China). Neutral detergent fiber and ADF contents were determined and expressed inclusive of residual ash according to Van Soest et al. (1991), and NDF was assayed with the addition of $\alpha$-amylase and without sodium sulfite. The starch content was determined after pre-extraction with ethanol (80\%), and glucose liberated from starch by enzyme hydrolysis was measured with the use of amyloglucosidase (Karthner and Theurer, 1981). 
Dissolved gases $\left(\mathrm{dH}_{2}\right.$ and $\left.\mathrm{dCH}_{4}\right)$ were extracted from the liquid phase of rumen contents to gas phase using the procedure by Wang et al. (2014) with slight modification. In brief, a $20-\mathrm{mL}$ syringe containing 10 $\mathrm{mL}$ of $\mathrm{N}_{2}$ gas $(>99.99 \%)$ was injected into a $50-\mathrm{mL}$ plastic syringe containing $35 \mathrm{~mL}$ of rumen content via polyurethane tubing. The gases dissolved in the liquid phase were exacted into the gas phase by shaking at 200 revolutions per second for $5 \mathrm{~min}$ in an orbital shaker (WSZ-100A, Shanghai Yiheng Scientific Instruments Co. Ltd., Shanghai, China). Gas samples were collected at evacuated tubes for subsequent analysis using GLC (Agilent 7890A, Agilent Inc., Palo Alto, CA; Wang et al., 2016a). Concentrations of $\mathrm{dH}_{2}$ and $\mathrm{dCH}_{4}$ in the original liquid fraction were calculated using the equations by Wang et al. (2016a).

Individual VFA concentrations were analyzed by GC (Agilent 7890A, Agilent Inc.) according to the method described by Wang et al. (2014). The estimated net $[2 \mathrm{H}]$ production relative to the amount of total VFA produced $\left(\mathbf{R}_{\mathrm{N2H}}\right)$ was calculated according to the stoichiometric equation developed by Wang et al. (2016a), under the assumption of equal fractional rates of absorption of individual VFA. Lactate and ammonia concentrations were measured according to the methods by Taylor (1996) and Weatherburn (1967), respectively. Ruminal fluid-associated microbes were isolated by differential centrifugation. First, samples of rumen fluid were centrifuged twice times at $500 \times g$ for $5 \mathrm{~min}$ at $3^{\circ} \mathrm{C}$. Then the supernatant was transferred into new plastic tubes and centrifuged at $17,300 \times g$ for $20 \mathrm{~min}$ at $3^{\circ} \mathrm{C}$, according to the method of Olijhoek et al. (2016). Feed particles were separated by centrifuging at $500 \times$ $g$ at $4^{\circ} \mathrm{C}$ for $10 \mathrm{~min}$, and the supernatant was further centrifuged at $20,000 \times g$ at $4^{\circ} \mathrm{C}$ for 20 min to obtain the pellet of fluid-associated microbes, which was further analyzed to obtain total $\mathrm{N}$ by using trichloroacetic acid (Klita et al., 1996). Total microbial $\mathrm{N}$ in the rumen contents was estimated using purines method with the ratio of purines to $\mathrm{N}$ of yeast as the standard (Zinn and Owens, 1986), and microbial $\mathrm{N}$ concentration was expressed as the amount of microbial $\mathrm{N}$ relative to the dry matter in the rumen contents $(\mathrm{g} / 100 \mathrm{~g}$ of DM in rumen content).

Nitrite concentration was measured using the Griess reagents sulfanilamide and $N$-(1-naphthyl) ethylenediamine to form a diazo-compound, which can be analyzed by flow injection analysis (Smart Chem 140, Ams-Systea, Rome, Italy; Wang et al., 2017). Total nitrate plus nitrite concentration was measured by converting nitrate to nitrite using the Griess reaction after pretreatment with hydrazine sulfate (Pons et al., 2008). Nitrate concentration was calculated by the difference between the total concentration of nitrate plus nitrite and the concentration of nitrite. Dissolved nitric oxide concentration was measured by reacting with chromogenic agent using the nitric oxide Colorimetric Assay Kit (A013, Nanjing Jiancheng Bioengineering Institute, Nanjing, China).

Total DNA was extracted from a pooled sample of rumen contents obtained through mixing 2 equal samples taken at 2.5 and $6 \mathrm{~h}$ after the morning feeding, using the QIAampDNA Stool Mini Kits (Qiagen GmbH, Hilden, Germany) following the manufacturer's procedures (Jiao et al., 2014). The quality of the DNA extracts were assessed using agarose gel $(0.8 \%)$ electrophoresis. Total DNA extracted was quantified with Nano Drop ND1000 (NanoDrop Technologies, Thermo Fisher Scientific, Waltham, MA), and then stored at $-80^{\circ} \mathrm{C}$ until further analyses. Quantitative real-time PCR analysis was performed on total bacteria, protozoa, fungi and methanogens, and selected groups of bacteria (Ruminococcus albus, Ruminococcus flavefaciens, Fibrobacter succinogenes, Selenomonas ruminantium, and Prevotella ruminicola), as well as Prevotella spp. The $16 \mathrm{~S}$ rRNA gene-targeted primers employed are shown in Table 2. Quantitative PCR results are expressed as copies of $16 \mathrm{~S}$ rRNA genes targeted per gram of rumen contents.

\section{Statistical Analysis}

Statistical analysis was performed using SPSS 19.0 software (SPSS Inc., Chicago, IL). All data were analyzed using a Mixed linear model including dietary treatment as fixed effects, and animal, period, and block as a random effect. When sampling time was considered, the model included dietary treatment, interaction between treatment and time as fixed effect, time as a repeated measurement, and period, animal, and block as random effect, with covariance being compound symmetry structure. Statistical significance of effects was declared at $P \leq 0.05$, and a tendency toward significance was declared $0.05<P \leq 0.10$.

Associations between propionate molar proportion, the acetate-to-propionate ratio, and $\mathrm{R}_{N 2 H}(\mathrm{y})$ with $\mathrm{dH}_{2}$ concentration were studied using the RStudio software (Horton and Kleinman, 2015). The regression model was

$$
\begin{gathered}
\mathrm{y}=\text { intercept }+\mathrm{dH}_{2}+\text { treatment }+ \text { time } \\
+\mathrm{dH}_{2} \times \text { treatment }+\mathrm{dH}_{2} \times \text { time }+ \text { residual } .
\end{gathered}
$$

\section{RESULTS}

Dietary nitrate did not alter $(P>0.50)$ total-tract digestibility of nutrients studied but it did increase milk yield $(P<0.01)$ and ECM production $(P<0.01)$ (Table 
Table 2. Primers used for quantitative PCR

\begin{tabular}{|c|c|c|c|c|c|}
\hline Target species & Primer & Primer sequences $\left(5^{\prime}\right.$ to $\left.3^{\prime}\right)$ & $\begin{array}{l}\text { Size } \\
(\mathrm{bp})\end{array}$ & Reference & $\begin{array}{c}\text { Primer } \\
\text { efficiency }(\%)\end{array}$ \\
\hline Bacteria & $\begin{array}{l}\text { Forward } \\
\text { Reverse }\end{array}$ & $\begin{array}{l}\text { CGGCAACGAGCGCAACCC } \\
\text { CCATTGTAGCACGTGTGTAGCC }\end{array}$ & 146 & $\begin{array}{l}\text { Denman and } \\
\text { McSweeney (2006) }\end{array}$ & 100.4 \\
\hline Methanogens & $\begin{array}{l}\text { Forward } \\
\text { Reverse }\end{array}$ & $\begin{array}{l}\text { GGATTAGATACCCSGGTAGT } \\
\text { GTTGARTCCAATTAAACCGCA }\end{array}$ & 192 & Hook et al. (2009) & 101.9 \\
\hline Prevotella spp. & $\begin{array}{l}\text { Forward } \\
\text { Reverse }\end{array}$ & $\begin{array}{l}\text { GGTTCTGAGAGGAAGGTCCCC } \\
\text { TCCTGCACGCTACTTGGCTG }\end{array}$ & 121 & $\begin{array}{l}\text { Stevenson and Weimer } \\
(2007)\end{array}$ & 95.3 \\
\hline Prevotella ruminicola & $\begin{array}{l}\text { Forward } \\
\text { Reverse }\end{array}$ & $\begin{array}{l}\text { GAAAGTCGGATTAATGCTCTATGTTG } \\
\text { CATCCTATAGCGGTAAACCTTTGG }\end{array}$ & 74 & $\begin{array}{l}\text { Stevenson and Weimer } \\
(2007)\end{array}$ & 99.8 \\
\hline Selenomonas ruminantium & $\begin{array}{l}\text { Forward } \\
\text { Reverse }\end{array}$ & $\begin{array}{l}\text { CAATAAGCATTCCGCCTGGG } \\
\text { TTCACTCAATGTCAAGCCCTGG }\end{array}$ & 138 & $\begin{array}{l}\text { Stevenson and Weimer } \\
(2007)\end{array}$ & 102.2 \\
\hline Ruminococcus albus & $\begin{array}{l}\text { Forward } \\
\text { Reverse }\end{array}$ & $\begin{array}{l}\text { CCCTAAAAGCAGTCTTAGTTCG } \\
\text { CCTCCTTGCGGTTAGAACA }\end{array}$ & 176 & $\begin{array}{l}\text { Koike and Kobayashi } \\
(2001)\end{array}$ & 101.3 \\
\hline
\end{tabular}

3). Cows fed nitrate had different kinetics of methane emissions compared with those fed urea, with higher $(P \leq 0.10)$ rate of methane emissions within $3 \mathrm{~h}$ after morning feeding (Figure 1). Nitrate supplementation decreased methane emissions in terms of grams per day $(-15.0 \% ; P=0.02)$, grams per kilogram of OM intake $(P=0.01)$, and grams per kilogram of OM digested $(P$ $=0.01)$. Nitrate supplementation did not alter carbon dioxide emissions $(P=0.68$; Table 3$)$.

Nitrate treatment resulted in greater ruminal nitrite $(P<0.01)$ and nitric oxide concentration $(P<0.01)$, and lower ammonia concentration $(P<0.01$; Table 4$)$. In plasma, nitrate treatment increased ruminal nitrite $(P<0.01)$ and nitric oxide concentration $(P<0.01)$ and decreased ammonia concentration $(P<0.01$; Table $4)$. We observed no interactions between treatment and time of sampling on metabolites concentration in the rumen and plasma $(P \geq 0.14)$.

Nitrate treatment resulted in greater ruminal $\mathrm{dH}_{2}$ concentration $(102 \% ; P<0.01)$ and propionate molar percentage $(P<0.01)$ as well as decreased acetateto-propionate ratio $(P<0.01)$ and $\mathrm{R}_{N 2 H}(P<0.01)$ in comparison with urea treatment (Table 5 ). Ruminal $\mathrm{dH}_{2}$ was positively correlated with propionate molar percentage $(\mathrm{r}=0.57 ; P<0.01)$ and negatively correlated with acetate-to-propionate ratio $(\mathrm{r}=-0.57 ; P$ $<0.01)$ and $\mathrm{R}_{N 2 H}(\mathrm{r}=-0.58 ; P<0.01$; Figure 2$)$. We found no significant effects of class (treatment and

Table 3. Feed intake, digestibility, and methane and carbon dioxide emissions in lactating dairy cows fed on urea or nitrate diet $(\mathrm{n}=8)$

\begin{tabular}{lcccc}
\hline & \multicolumn{2}{c}{ Treatment } & & \\
\cline { 2 - 3 } Item & Urea & Nitrate & SEM & $P$-value \\
\hline DMI (kg/d) & 10.2 & 10.2 & - & \\
Apparent total-tract digestibility (\%) & & & & \\
OM & 74.2 & 74.8 & 1.30 & 0.62 \\
CP & 62.2 & 62.1 & 1.83 & 0.96 \\
NDF & 65.1 & 66.0 & 1.48 & 0.58 \\
ADF & 56.4 & 57.2 & 1.38 & 0.58 \\
Starch & 97.1 & 97.1 & 0.13 & 0.83 \\
Milk yield (kg/d) & 15.9 & 16.5 & 0.11 & $<0.01$ \\
ECM production (kg/d) & 14.4 & 15.1 & 0.12 & $<0.01$ \\
Methane emissions & & & & \\
g/d & 206 & 175 & 10.4 & 0.02 \\
g/kg of OM intake & 22.6 & 19.3 & 0.95 & 0.01 \\
g/kg of OM digested & 30.5 & 25.9 & 1.38 & 0.01 \\
Carbon dioxide emissions (kg/d) & 8.99 & 8.87 & 0.247 & 0.66 \\
\hline
\end{tabular}


Table 4. Nitrate, nitrite, and ammonia in the rumen and plasma of dairy cows fed on urea or nitrate diet $(\mathrm{n}=8)$

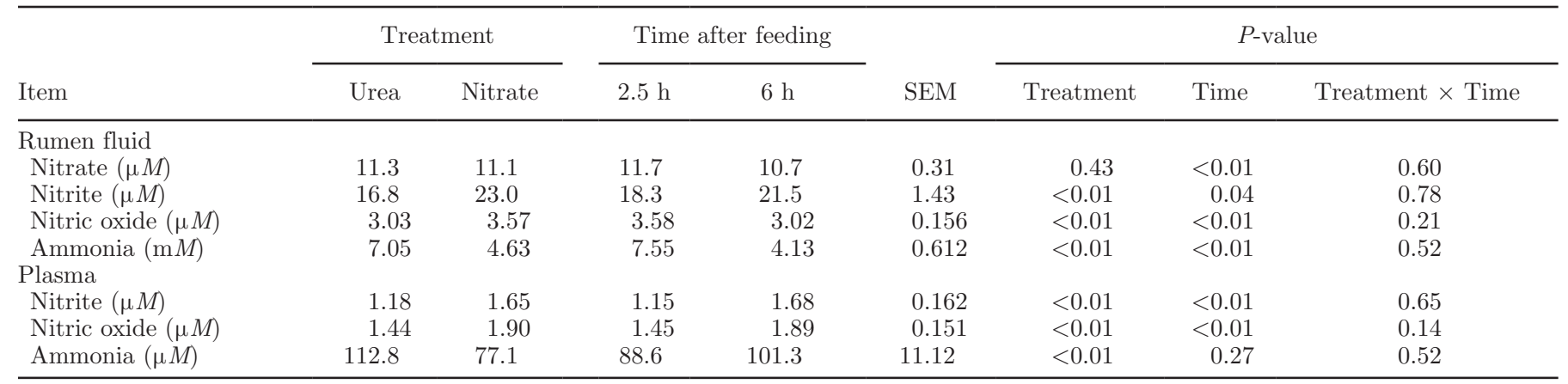

time) and its interactions with the continuous $\mathrm{dH}_{2}$. The nitrate treatment resulted in greater fluid-associated microbial $\mathrm{N}$ concentration $(3.74 \% ; P<0.01)$ and microbial $\mathrm{N}(22.8 \% ; P<0.01)$ in rumen content. We observed no interaction between the effect of treatment and time of sampling on dissolved gases concentration $(P \geq 0.10)$. The nitrate treatment had greater the $16 \mathrm{~S}$ rRNA gene copies of $S$. ruminantium $(P=0.01)$ and Prevotella spp. $(P=0.07)$ compared with the urea treatment (Table 6$)$.

\section{DISCUSSION}

Nitrate supplementation did not alter fiber digestibility, which was consistent with lack of changes in 16S rRNA gene copies of known major ruminal fiberdegrading fungi and fibrolytic bacteria $R$. albus, $R$. flavefaciens, and $F$. succinogenes; however, this is not in agreement with several published reports. Some studies indicated that nitrate inhibits microorganisms by degrading plant cell walls, leading to the decreased

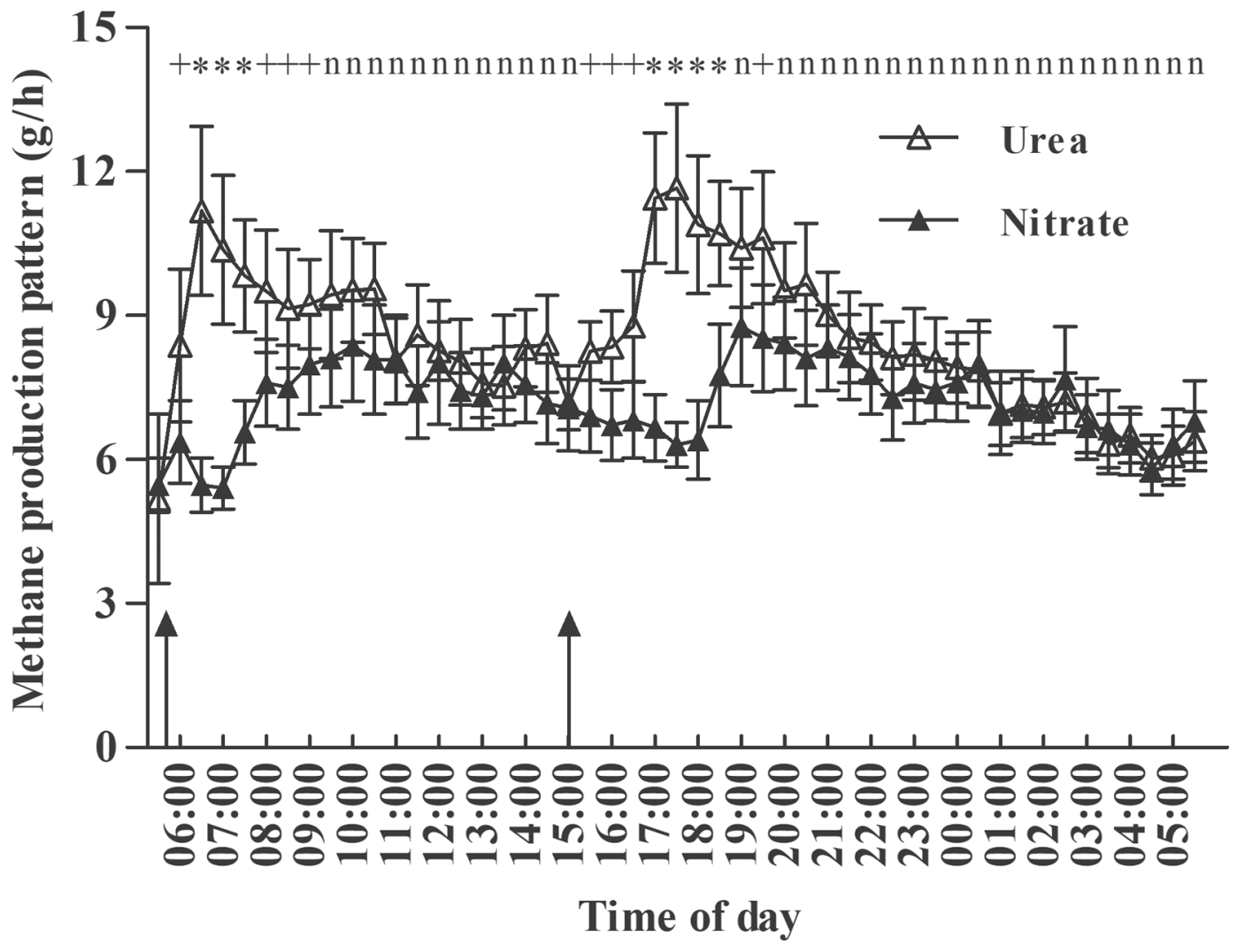

Figure 1. Diurnal methane production pattern $(\mathrm{g} / \mathrm{h}$, means \pm SEM) over a 24 -h period in dairy cows fed by urea diet $(\Delta)$ or nitrate diet $(\Lambda)(\mathrm{n}=8)$. Arrows indicate the time of feeding. Symbols indicate whether the treatment effect was significant for the respective time point: ${ }^{*} P \leq 0.05,+0.05<P \leq 0.10,{ }^{\mathrm{n}} P>0.10$. 
fiber digestion (Marais et al., 1988; Klop et al., 2016), whereas others reported that nitrate increases cellulolytic bacteria, resulting in increased fiber digestibility (Patra and $\mathrm{Yu}$ (2015). These inconsistent effects of nitrate supplementation on fiber digestibility may be due to differences in dosage supplemented, efficiency of ruminal nitrate reduction, experiment methods (in vitro or in vivo), and ruminant species, among others.

Nitrite is an intermediate during the reduction of nitrate to ammonia (Guyader et al., 2015; Troy et al., 2015). Because the reduction of nitrate to nitrite is generally faster than the reduction of nitrite to ammonia, nitrite can accumulate in the rumen fluid and be absorbed through the rumen wall and enter blood circulation (Olijhoek et al., 2016). Once in the blood, nitrite oxidizes ferrous iron $\left(\mathrm{Fe}^{2+}\right)$ in hemoglobin to ferric iron $\left(\mathrm{Fe}^{3+}\right)$; as a consequence, the hemoglobin molecule is impaired to transport oxygen to the tissues (Ozmen et al., 2005; van Zijderveld et al., 2011). In our study, both nitrate and nitrite were detected in the rumen contents and plasma of cows fed the control diet with urea supplementation, which might have been caused by nitrate present in the corn silage component of the diet, as farmers used excess nitrogenous fertilizer containing nitrate to grow the corn (Takahashi et al., 1998; Wang et al., 2018). However, nitrate and nitrite concentration were very low, within ranges from 10.5 to 11.8 and 15.4 to $24.7 \mu M$ in the rumen with both treatments, indicating that the dietary nitrate was almost completely chemically reduced. Such low ruminal nitrate and nitrite concentrations cannot have been high enough to cause occurrence of methemoglobinemia, in agreement with previous results reported by Veneman et al. (2015).

Nitrate reduction to ammonia is thermodynamically more favorable than carbon dioxide reduction to methane in the rumen, leading to redirection of $[\mathrm{H}]$ flow away from methanogenesis and toward ammonia production (Latham et al., 2016). In the rumen, dietary urea is hydrolyzed to ammonia, a neutral reaction in terms of release or incorporation of $[\mathrm{H}]$ release or incorporation. Previous studies have shown that replacing urea with nitrate decreases 10 to $35 \%$ of daily methane emissions ( $\mathrm{Li}$ et al., 2012; de Raphlis-Soissan et al., 2014; Guyader et al., 2015; Lee et al., 2015; Klop et al., 2016). In our study, replacing urea with nitrate decreased daily methane emission in dairy cows by about $15 \%$ (i.e., $31 \mathrm{~g} / \mathrm{d}$ ), which is $82 \%$ of the theoretical maximum potential to reduce methane (i.e., $38 \mathrm{~g} / \mathrm{d}$ ) by $149 \mathrm{~g} / \mathrm{d}$ of nitrate intake. Such a shift of [H] flow from methanogenesis to ammonia production may have caused the enhancement of rumen microbial activity and cow productivity with the low-protein diet evaluated in the current study. However, when nitrate is supplemented to a diet (in exchange with urea) already sufficient in protein, dietary $\mathrm{N}$ may not lead to a more efficient rumen fermentation, as evidenced by increased ruminal ammonia concentration (Hulshof et al., 2012; Guyader et al., 2015; Olijhoek et al., 2016). The inefficient nitrate-N utilization may be due to absorption of excess ammonia through the rumen wall and elimination of most $\mathrm{N}$ as urea in urine (Wallace et al., 1997) as well as incomplete reduction of nitrate to ammonia and microbial protein synthesis by rumen microorganisms

Table 5. Dissolved gases and fermentation end-products in the rumen of dairy cattle fed on urea or nitrate diet $(\mathrm{n}=8)$

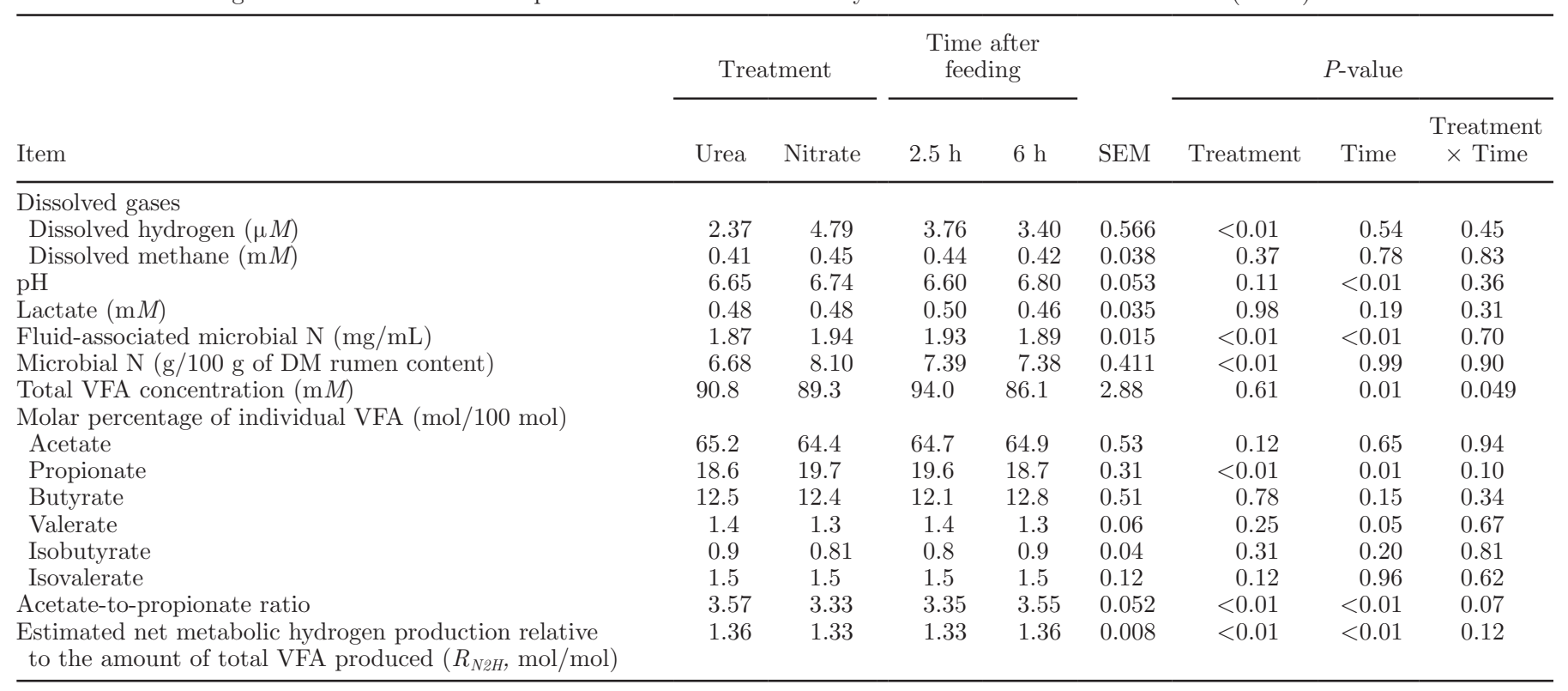



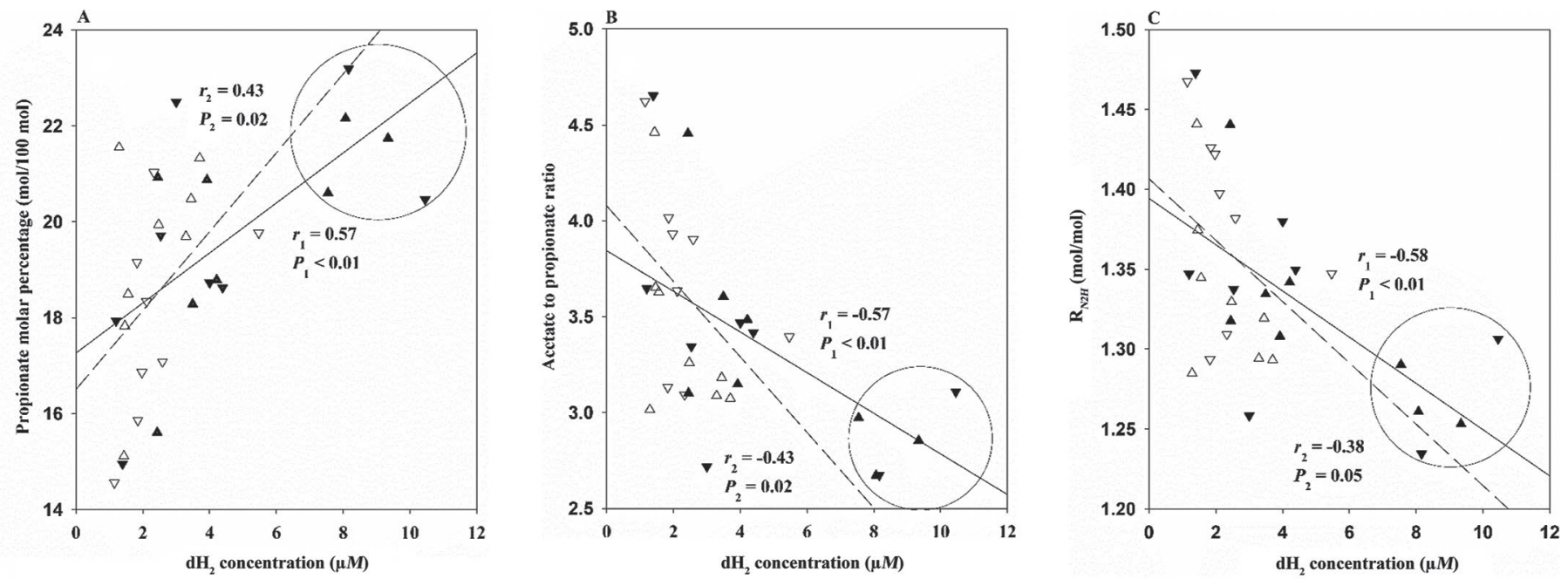

Figure 2. Association of selected fermentation variables with dissolved hydrogen $\left(\mathrm{dH}_{2}\right)(\mathrm{n}=32)$. (A) Propionate molar percentage: y $=18.1$ $( \pm 1.25 ; P<0.01)+0.41( \pm 0.239 ; P=0.09) \mathrm{dH}_{2}-1.10( \pm 1.25 ; P=0.30)$ time $-1.14( \pm 1.537 ; P=0.47)$ treatment $+0.09( \pm 0.288 ; P=0.76)$ $\mathrm{dH}_{2} \times$ time $-0.46( \pm 0.486 ; P=0.35) \mathrm{dH}_{2} \times$ treatment. $(\mathrm{B})$ Acetate-to-propionate ratio: $\mathrm{y}=3.83( \pm 0.301 ; P<0.01)-0.12( \pm 0.057 ; P=0.04)$ $\mathrm{dH}_{2}+0.144( \pm 0.301 ; P=0.64)$ time $+0.14( \pm 0.369 ; P=0.70)$ treatment $+0.003( \pm 0.069 ; P=0.96) \mathrm{dH}_{2} \times$ time $-0.081( \pm 0.117 ; P=0.49)$ $\mathrm{dH}_{2} \times$ treatment. (C) Estimated net metabolic hydrogen production relative to the amount of total VFA produced $\left(R_{N 2 H}\right): y=1.38( \pm 0.034 ;$ $P<0.01)-0.01( \pm 0.007 ; P=0.04) \mathrm{dH}_{2}+0.003( \pm 0.034 ; P=0.43)$ time $+0.01( \pm 0.04 ; P=0.73)$ treatment $-0.0002( \pm 0.008 ; P=0.98)$ $\mathrm{dH}_{2} \times$ time $-0.007( \pm 0.013 ; P=0.60) \mathrm{dH}_{2} \times$ treatment. $\Delta=$ data collected at $2.5 \mathrm{~h}$ postfeeding of urea treatment; $\nabla=$ data collected at 6 $\mathrm{h}$ postfeeding of urea treatment; $\boldsymbol{\Delta}=$ data collected at $2.5 \mathrm{~h}$ postfeeding of nitrate treatment; $\boldsymbol{\nabla}=$ data collected at $6 \mathrm{~h}$ postfeeding of nitrate treatment. The solid line represents the regression line fitted using all data points $\left(r_{1}\right.$ and $\left.P_{1}\right)$; the dashed line represents the regression line $\left(r_{2}\right.$ and $P_{2}$ ) fitted after removing the 5 influential points in the circle.

(van Zijderveld et al., 2011; Olijhoek et al., 2016). In contrast, in the present study the diet had a relatively low $\mathrm{CP}$ content ( $11 \%$ including the supplementation), and the supplemented nitrate resulted in lower ammonia concentration in the rumen liquid and blood and a greater microbial protein content in the rumen compared with urea supplementation. These results suggest an enhancement of ammonia utilization in dairy cows supplemented with nitrate, in agreement with previous in vitro results (Guo et al., 2009). Enhancement of ammonia utilization may redirect more N, electrons,

Table 6. Selected groups microorganisms $\left(\log _{10}\right.$ copies/DM rumen contents) in the rumen of dairy cows fed on urea or nitrate diet $(\mathrm{n}=8)$

\begin{tabular}{|c|c|c|c|c|}
\hline \multirow[b]{2}{*}{ Item } & \multicolumn{2}{|c|}{ Treatment } & \multirow[b]{2}{*}{ SEM } & \multirow[b]{2}{*}{$P$-value } \\
\hline & Urea & Nitrate & & \\
\hline Bacteria & 11.33 & 11.41 & 0.059 & 0.26 \\
\hline Protozoa & 8.68 & 8.59 & 0.192 & 0.67 \\
\hline Methanogens & 8.92 & 8.85 & 0.076 & 0.42 \\
\hline Fungi & 7.36 & 7.44 & 0.145 & 0.62 \\
\hline \multicolumn{5}{|l|}{ Selected groups of bacteria } \\
\hline Prevotella spp. & 10.84 & 10.94 & 0.047 & 0.07 \\
\hline Prevotella ruminicola & 10.02 & 10.00 & 0.052 & 0.68 \\
\hline Selenomonas ruminantium & 8.49 & 8.69 & 0.061 & 0.01 \\
\hline Ruminococcus albus & 7.94 & 8.03 & 0.050 & 0.13 \\
\hline Ruminococcus flavefaciens & 7.12 & 7.08 & 0.153 & 0.77 \\
\hline Fibrobacter succinogenes & 9.56 & 9.72 & 0.082 & 0.11 \\
\hline
\end{tabular}

and energy toward microbial protein synthesis at the expense of methane emissions.

On the other hand, nitrate may also have negative effects through the production of nitrite, which is probably toxic to microbial cells (Marais et al., 1988; Cammack et al., 1999). However, nitrate supplementation at the dose applied in the present study did not affect $16 \mathrm{~S}$ rRNA copies of bacteria, protozoa, methanogens, or fungi. The toxic effect of nitrite can suppress growth and activity of methanogens (Iwamoto et al., 2001; van Zijderveld et al., 2010), decrease the rate of $\mathrm{H}_{2}$ utilization by methanogenesis, and cause ruminal $\mathrm{H}_{2}$ accumulation. Guyader et al. (2015) reported that nitrate supplementation induced a 12.5 -fold peak of $\mathrm{dH}_{2}$ concentration in the rumen up to $2 \mathrm{~h}$ after commencement of feeding, which coincides with a previously reported increase in gaseous $\mathrm{H}_{2}$ emissions (van Zijderveld et al., 2011). In our study, nitrate supplementation resulted in greater ruminal $\mathrm{dH}_{2}$ concentration than urea supplementation, but the increase was lower compared with the study by Guyader et al. (2015; 12.5 vs. 2.02 fold with respect to the urea controls), which is likely due to the difference in nitrate dose that was applied (22.7 vs. $14.6 \mathrm{~g} / \mathrm{kg}$ of DM) and perhaps to the different techniques employed for measuring $\mathrm{dH}_{2}$ concentration.

Nitrate acts as an electron acceptor in anaerobic environments, and the reduction of nitrate to nitrite or 
ammonia can alter the flows of $[\mathrm{H}]$ in the rumen. Studies have indicated that nitrate supplementation increased acetate molar percentage, because nitrate reduction favors the release of $[\mathrm{H}]$ with increased growth of acetate producers (Patra and $\mathrm{Yu}, 2015$ ) and acetate molar percentage (Hulshof et al., 2012; Troy et al., 2015). This mechanism, however, is in contradiction with the elevated ruminal $\mathrm{dH}_{2}$ and the increase in gaseous $\mathrm{H}_{2}$ emission, also reported previously (van Zijderveld et al., 2011; Guyader et al., 2015), because nitrate reduction, being thermodynamically favorable, would be expected to decrease the availability of ruminal $\mathrm{H}_{2}$. In our study, nitrate supplementation increased propionate molar percentage and decreased acetate-to-propionate ratio and the efficiency of $[\mathrm{H}]$ production derived from fermentation, presumably leading to an increase in the incorporation of $[\mathrm{H}]$ into propionate formation. Such a shift of fermentation pathways from acetate to propionate production agrees with increased $\mathrm{dH}_{2}$ concentration, because propionogenesis is considered to be thermodynamically favored by increased $\mathrm{H}_{2}$ partial pressures (Ellis et al., 2008; Janssen, 2010). Ungerfeld (2013) proposed that $[\mathrm{H}]$ can also be redirected into propionogenesis under higher $\mathrm{H}_{2}$ partial pressure. Such a shift of $[\mathrm{H}]$ flow from methanogenesis to VFA would also contribute to redirecting electrons and energy in rumen metabolites, which is consistent with increased milk and ECM production.

It is well known that fiber digestion is associated with greater acetate-to-propionate concentration ratio compared with concentrates. Ruminococcus flavefaciens and $R$. albus produce a fermentation profile with a high acetate-to-propionate ratio. In fact, $F$. succinogenes grown in pure cultures produces a good deal of succinate (Bryant and Doetsch, 1954; Dehority, 1963; Weimer, 1993; Rychlik and May, 2000), a propionate precursor, and to a lesser extent so does $R$. flavefaciens (Dehority, 1963; Latham and Wolin, 1977; Shi and Weimer, 1992; Sawanon and Kobayashi, 2006). Furthermore, the proportion of $F$. succinogenes, $R$. flavefaciens, and $R$. albus in total bacterial $16 \mathrm{~S}$ rRNA copies is relatively small; therefore, it is not clear that changes in the abundance of these fibrolytic bacteria are reflected in changes in the concentration of fermentation end-products. Exposure of animals to a gradual increment in dietary nitrate helps promote the growth of nitrite reducing bacteria in the rumen (Zhou et al., 2012; Asanuma et al., 2015). Selenomonas ruminantium is reported to be active in nitrate and nitrite reduction, and its abundance was increased by feeding a nitrate-containing diet (Asanuma et al., 2015). Reduction of nitrate by S. ruminantium is associated with phosphorylation of ADP to ATP via electron transport-linked phosphorylation (Hasan and Hall, 1975). In agreement, we found that cows fed the nitrate diet had greater $16 \mathrm{~S}$ rRNA gene copies of $S$. ruminantium than those fed with the urea diet. In addition, nitrate supplementation tended to increase population of Prevotella spp., which may partially contribute to the increased propionate molar proportion (Wang et al., 2016b).

\section{CONCLUSIONS}

When cows were fed a low-protein diet, replacing urea with nitrate seemed to improve ammonia incorporation into microbial protein and stimulate the disposition of electrons derived from fermentation into propionate production, which might have stimulated milk and ECM production. Increased $16 \mathrm{~S}$ rRNA gene copies of S. ruminantium likely contributed to the reduction of nitrate to ammonia and the shift of fermentation toward propionate production. Overall, nitrate seemed to shift $[\mathrm{H}]$ flows from methanogenesis toward propionate and increase ammonia utilization for microbial $\mathrm{CP}$ synthesis, which benefited the host animals on this lowprotein diet.

\section{ACKNOWLEDGMENTS}

This work was supported by National Key Research and Development Program of China (Grant No. 2016YFD0500504 and 2018YFD0501800), National Natural Science Foundation of China (Grant No. 31561143009 and 31472133), State Key Laboratory of Animal Nutrition (Grant No. 2004DA125184F1705), China Agriculture Research System (Grant No. CARS36), Major Project of Hunan Province(2017NK1020), Youth Innovation Promotion Association CAS (Grant No.2016327), CAS President's International Fellowship (Grant No. 2018VBA0031). The authors declare that they have no conflict of interest. We acknowledge the work of M. W., R. W., J. P. D., and Z. L. T., who designed the research; R. W., X. M. Z., D. L. L., and H. X. M., who conducted the research; R. W. and M. W., who analyzed the data; and R. W., M. W., E. M. U., A. B., and Z. L. T., who wrote the paper. R. W. and M. W. had primary responsibility for the final content. All authors read and approved the final manuscript.

\section{REFERENCES}

AOAC International. 2000. Official Methods of Analysis. 17th ed. Vols. 1 and 2. 17th ed. AOAC International, Gaithersburg, MD.

Asanuma, N., S. Yokoyama, and T. Hino. 2015. Effects of nitrate addition to a diet on fermentation and microbial populations in the rumen of goats, with special reference to Selenomonas ruminantium having the ability to reduce nitrate and nitrite. Anim. Sci. J. 86:378-384. https://doi.org/10.1111/asj.12307.

Boston, R., D. Fox, C. Sniffen, E. Janczewski, R. Munson, and W Chalupa. 2000. The conversion of a scientific model describing 
dairy cow nutrition and production to an industry tool: The CPM Dairy project. Pages 361-377 in Modelling Nutrient Utilization in Farm Animals. J. P. McNamara, J. France, and D. Beever, ed. CABI Publishing, Oxford, UK. https://doi.org/10.1079/ 9780851994499.0361.

Bryant, M. P., and R. N. Doetsch. 1954. A study of actively cellulolytic rod-shaped bacteria of the bovine rumen. J. Dairy Sci. 37:11761183. https://doi.org/10.3168/jds.S0022-0302(54)91387-9.

Cammack, R., C. L. Joannou, X.-Y. Cui, C. Torres Martinez, S. R. Maraj, and M. N. Hughes. 1999. Nitrite and nitrosyl compounds in food preservation. BBA Bioenergetics 1411:475-488. https://doi .org/10.1016/S0005-2728(99)00033-X.

de Raphlis-Soissan, V., L. Li, I. R. Godwin, M. C. Barnett, H. B. Perdok, and R. S. Hegarty. 2014. Use of nitrate and Propionibacterium acidipropionici to reduce methane emissions and increase wool growth of Merino sheep. Anim. Prod. Sci. 54:1860-1866. https:// doi.org/10.1071/AN14329

Dehority, B. A. 1963. Isolation and characterization of several cellulolytic bacteria from in vitro rumen fermentations. J. Dairy Sci. 46:217-222. https://doi.org/10.3168/jds.S0022-0302(63)89009-8.

Denman, S. E., and C. S. McSweeney. 2006. Development of a realtime PCR assay for monitoring anaerobic fungal and cellulolytic bacterial populations within the rumen. FEMS Microbiol. Ecol. 58:572-582. https://doi.org/10.1111/j.1574-6941.2006.00190.x.

Ellis, J., J. Dijkstra, E. Kebreab, A. Bannink, N. Odongo, B. McBride, and J. France. 2008. Aspects of rumen microbiology central to mechanistic modelling of methane production in cattle. J. Agric. Sci. 146:213-233. https://doi.org/10.1017/S0021859608007752.

Guo, W., D. Schaefer, X. Guo, L. Ren, and Q. Meng. 2009. Use of nitrate-nitrogen as a sole dietary nitrogen source to inhibit ruminal methanogenesis and to improve microbial nitrogen synthesis in vitro. Asian-Aust. J. Anim. Sci. 22:542-549. https://doi.org/10 .5713 /ajas.2009.80361.

Guyader, J., M. Eugene, B. Meunier, M. Doreau, D. P. Morgavi, M. Silberberg, Y. Rochette, C. Gerard, C. Loncke, and C. Martin. 2015. Additive methane-mitigating effect between linseed oil and nitrate fed to cattle. J. Anim. Sci. 93:3564-3577. https://doi.org/ 10.2527 /jas.2014-8196.

Hasan, S. M., and J. Hall. 1975. The physiological function of nitrate reduction in Clostridium perfringens. J. Gen. Microbiol. 87:120128. https://doi.org/10.1099/00221287-87-1-120

Hook, S. E., K. S. Northwood, A.-D. Wright, and B. W. McBride. 2009. Long-term monensin supplementation does not significantly affect the quantity or diversity of methanogens in the rumen of the lactating dairy cow. Appl. Environ. Microbiol. 75:374-380. https:/ /doi.org/10.1128/AEM.01672-08.

Horton, N. J., and K. Kleinman. 2015. Using R and RStudio for Data Management, Statistical Analysis, and Graphics. CRC Press, Boca Raton. FL.

Hristov, A. N., and G. A. Broderick. 1996. Synthesis of microbial protein in ruminally cannulated cows fed alfalfa silage, alfalfa hay, or corn silage. J. Dairy Sci. 79:1627-1637. https://doi.org/10.3168/ jds.S0022-0302(96)76526-8.

Hulshof, R. B.. A. Berndt, W. Gerrits, J. Dijkstra, S. Van Zijderveld, J. Newbold, and H. Perdok. 2012. Dietary nitrate supplementation reduces methane emission in beef cattle fed sugarcane-based diets. J. Anim. Sci. 90:2317-2323. https://doi.org/10.2527/jas.2011 $-4209$

Hungate, R. E. 1967. Hydrogen as an intermediate in the rumen fermentation. Arch. Mikrobiol. 59:158-164. https://doi.org/10.1007/ BF00406327.

Iwamoto, M., N. Asanuma, and T. Hino. 2001. Effects of energy substrates on nitrate reduction and nitrate reductase activity in a ruminal bacterium, Selenomonas ruminantium. Anaerobe 7:315-321. https://doi.org/10.1006/anae.2001.0397.

Janssen, P. H. 2010. Influence of hydrogen on rumen methane formation and fermentation balances through microbial growth kinetics and fermentation thermodynamics. Anim. Feed Sci. Technol. 160:1-22. https://doi.org/10.1016/j.anifeedsci.2010.07.002.

Jiao, J., Q. Lu, Z. Tan, L. Guan, C. Zhou, S. Tang, and X. Han. 2014 In vitro evaluation of effects of gut region and fiber structure on the intestinal dominant bacterial diversity and functional bacterial species. Anaerobe 28:168-177. https://doi.org/10.1016/j.anaerobe .2014.06.008.

Johnson, K. A., and D. E. Johnson. 1995. Methane emissions from cattle. J. Anim. Sci. 73:2483-2492. https://doi.org/10.2527/1995 $.7382483 x$

Karthner, R. J., and B. Theurer. 1981. Comparison of hydrolysis methods used in feed, digesta, and fecal starch analysis. J. Agric. Food Chem. 29:8-11. https://doi.org/10.1021/jf00103a003.

Klita, P. T., G. W. Mathison, T. W. Fenton, and R. T. Hardin. 1996 Effects of alfalfa root saponins on digestive function in sheep. J. Anim. Sci. 74:1144-1156. https://doi.org/10.2527/1996.7451144x.

Klop, G., B. Hatew, A. Bannink, and J. Dijkstra. 2016. Feeding nitrate and docosahexaenoic acid affects enteric methane production and milk fatty acid composition in lactating dairy cows. J. Dairy Sci 99:1161-1172. https://doi.org/10.3168/jds.2015-10214.

Koike, S., and Y. Kobayashi. 2001. Development and use of competitive PCR assays for the rumen cellulolytic bacteria: Fibrobacter succinogenes, Ruminococcus albus and Ruminococcus flavefaciens. FEMS. Microbiol. Lett. 204:361-366. https://doi.org/10.1111/j .1574-6968.2001.tb10911.x.

Latham, E. A., R. C. Anderson, W. E. Pinchak, and D. J. Nisbet. 2016. Insights on alterations to the rumen ecosystem by nitrate and nitrocompounds. Front. Microbiol. 7. https://doi.org/10 3389 /fmicb.2016.00228.

Latham, M. J., and M. J. Wolin. 1977. Fermentation of cellulose by Ruminococcus flavefaciens in the presence and absence of Methanobacterium ruminantium. Appl. Environ. Microbiol. 34:297-301.

Lee, C., R. Araujo, K. Koenig, and K. Beauchemin. 2015. Effects of encapsulated nitrate on enteric methane production and nitrogen and energy utilization in beef heifers. J. Anim. Sci. 93:2391-2404. https://doi.org/10.2527/jas.2014-8845.

Lee, C., R. C. Araujo, K. M. Koenig, and K. A. Beauchemin. 2017. In situ and in vitro evaluations of a slow release form of nitrate for ruminants: Nitrate release rate, rumen nitrate metabolism and the production of methane, hydrogen, and nitrous oxide. Anim. Feed Sci. Technol. 231:97-106. https://doi.org/10.1016/j.anifeedsci 2017.07.005.

Lee, C., and K. A. Beauchemin. 2014. A review of feeding supplementary nitrate to ruminant animals: Nitrate toxicity, methane emissions, and production performance. Can. J. Anim. Sci. 94:557-570. https://doi.org/10.4141/CJAS-2014-069.

Li, L., J. Davis, J. Nolan, and R. Hegarty. 2012. An initial investigation on rumen fermentation pattern and methane emission of sheep offered diets containing urea or nitrate as the nitrogen source. Anim. Prod. Sci. 52:653-658. https://doi.org/10.1071/AN11254.

Marais, J. P., J. J. Therion, R. Mackie, A. Kistner, and C. Dennison. 1988. Effect of nitrate and its reduction products on the growth and activity of the rumen microbial population. Br. J. Nutr. 59:301-313. https://doi.org/10.1079/BJN19880037.

Nolan, J. V., R. S. Hegarty, J. Hegarty, I. R. Godwin, and R. Woodgate. 2010. Effects of dietary nitrate on fermentation, methane production and digesta kinetics in sheep. Anim. Prod. Sci. 50:801806. https://doi.org/10.1071/AN09211.

Olijhoek, D. W., A. L. F. Hellwing, M. Brask, M. R. Weisbjerg, O. Hojberg, M. K. Larsen, J. Dijkstra, E. J. Erlandsen, and P. Lund 2016. Effect of dietary nitrate level on enteric methane production, hydrogen emission, rumen fermentation, and nutrient digestibility in dairy cows. J. Dairy Sci. 99:6191-6205. https://doi.org/10 $.3168 /$ jds.2015-10691.

Ozmen, O., F. Mor, S. Sahinduran, and A. Unsal. 2005. Pathological and toxicological investigations of chronic nitrate poisoning in cattle. Toxicol. Environ. Chem. 87:99-106. https://doi.org/10 $.1080 / 02772240400007104$.

Patra, A. K., and Z. Yu. 2015. Effects of garlic oil, nitrate, saponin and their combinations supplemented to different substrates on in vitro fermentation, ruminal methanogenesis, and abundance and diversity of microbial populations. J. Appl. Microbiol. 119:127-138. https://doi.org/10.1111/jam.12819.

Pons, C., J. L. Santos, J. L. Lima, R. Forteza, and V. Cerdà. 2008 Multi-pumping flow system for the determination of nitrite and 
nitrate in water samples. Mikrochim. Acta 161:73-79. https://doi org/10.1007/s00604-007-0822-z.

Reisinger, A., and H. Clark. 2018. How much do direct livestock emissions actually contribute to global warming? Glob. Chang. Biol. 24:1749-1761. https://doi.org/10.1111/gcb.13975.

Rychlik, J. L., and T. May. 2000. The effect of a methanogen, Methanobrevibacter smithii, on the growth rate, organic acid production, and specific ATP activity of three predominant ruminal cellulolytic bacteria. Curr. Microbiol. 40:176-180.

Sawanon, S., and Y. Kobayashi. 2006. Synergistic fibrolysis in the rumen by cellulolytic Ruminococcus flavefaciens and non-cellulolytic Selenomonas ruminantium: Evidence in defined cultures. Anim. Sci. J. 77:208-214. https://doi.org/10.1111/j.1740-0929.2006 $.00339 . \mathrm{x}$

Shi, Y., and P. J. Weimer. 1992. Response surface analysis of the effects of $\mathrm{pH}$ and dilution rate on Ruminococcus flavefaciens FD-1 in cellulose-fed continuous culture. Appl. Environ. Microbiol. 58:2583-2591.

Sinclair, L. A., P. C. Garnsworthy, J. R. Newbold, and P. J. Buttery. 1993. Effect of synchronizing the rate of dietary energy and nitrogen release on rumen fermentation and microbial protein-synthesis in sheep. J. Agric. Sci. 120:251-263. https://doi.org/10.1017/ S002185960007430X.

Stevenson, D. M., and P. J. Weimer. 2007. Dominance of Prevotella and low abundance of classical ruminal bacterial species in the bovine rumen revealed by relative quantification real-time PCR. Appl. Microbiol. Biotechnol. 75:165-174. https://doi.org/10.1007/ s00253-006-0802-y.

Sylvester, J. T., S. K. Karnati, Z. Yu, M. Morrison, and J. L. Firkins. 2004. Development of an assay to quantify rumen ciliate protozoal biomass in cows using real-time PCR. J. Nutr. 134:3378-3384. https://doi.org/10.1093/jn/134.12.3378.

Takahashi, J., M. Ikeda, S. Matsuoka, and H. Fujita. 1998. Prophylactic effect of L-cysteine to acute and subclinical nitrate toxicity in sheep. Anim. Feed Sci. Technol. 74:273-280. https://doi.org/10 .1016/S0377-8401(98)00176-X.

Taylor, K. A. 1996. A simple colorimetric assay for muramic acid and lactic acid. Appl. Biochem. Biotechnol. 56:49-58. https://doi.org/ 10.1007/BF02787869.

Troy, S. M., C. Duthie, J. Hyslop, R. Roehe, D. Ross, R. Wallace, A. Waterhouse, and J. Rooke. 2015. Effectiveness of nitrate addition and increased oil content as methane mitigation strategies for beef cattle fed two contrasting basal diets. J. Anim. Sci. 93:1815-1823. https://doi.org/10.2527/jas.2014-8688.

Ungerfeld, E. M. 2013. A theoretical comparison between two ruminal electron sinks. Front. Microbiol. 4:319. https://doi.org/10.3389/ fmicb.2013.00319.

Van Soest, P. J., J. Robertson, and B. Lewis. 1991. Symposium: carbohydrate methodology, metabolism, and nutritional implications in dairy cattle. J. Dairy Sci. 74:3583-3597.

van Zijderveld, S. M., W. J. Gerrits, J. A. Apajalahti, J. R. Newbold, J. Dijkstra, R. A. Leng, and H. B. Perdok. 2010. Nitrate and sulfate: Effective alternative hydrogen sinks for mitigation of ruminal methane production in sheep. J. Dairy Sci. 93:5856-5866. https:// doi.org/10.3168/jds.2010-3281.

van Zijderveld, S. M., W. J. Gerrits, J. Dijkstra, J. R. Newbold, R. B. Hulshof, and H. B. Perdok. 2011. Persistency of methane mitiga- tion by dietary nitrate supplementation in dairy cows. J. Dairy Sci. 94:4028-4038. https://doi.org/10.3168/jds.2011-4236.

Veneman, J. B., S. Muetzel, K. J. Hart, C. L. Faulkner, J. M. Moorby, H. B. Perdok, and C. J. Newbold. 2015. Does dietary mitigation of enteric methane production affect rumen function and animal productivity in dairy cows? PLoS One 10:e0140282. https://doi .org/10.1371/journal.pone.0140282.

Wallace, R., R. Onodera, and M. Cotta. 1997. Metabolism of nitrogencontaining compounds. Pages 283-328 in The Rumen Microbial Ecosystem. P. N. Hobson and C. S. Stewart, ed. Blackie Academic and Professional, London, UK. https://doi.org/10.1007/978-94 -009-1453-7_7.

Wang, D., G. Li, Y. Mo, M. Cai, and X. Bian. 2018. Evaluation of optimal nitrogen rate for corn production under mulched drip fertigation and economic benefits. Field Crops Res. 216:225-233. https: //doi.org/10.1016/j.fcr.2017.10.002.

Wang, M., X. Z. Sun, P. H. Janssen, S. X. Tang, and Z. L. Tan. 2014. Responses of methane production and fermentation pathways to the increased dissolved hydrogen concentration generated by eight substrates in in vitro ruminal cultures. Anim. Feed Sci. Technol. 194:1-11. https://doi.org/10.1016/j.anifeedsci.2014.04.012.

Wang, M., R. Wang, P. H. Janssen, X. M. Zhang, X. Z. Sun, D. Pacheco, and Z. L. Tan. 2016a. Sampling procedure for the measurement of dissolved hydrogen and volatile fatty acids in the rumen of dairy cows. J. Anim. Sci. 94:1159-1169. https://doi.org/10.2527/ jas.2015-9658.

Wang, M., R. Wang, X. Sun, L. Chen, S. Tang, C. Zhou, X. Han, J. Kang, Z. Tan, and Z. He. 2015. A mathematical model to describe the diurnal pattern of enteric methane emissions from non-lactating dairy cows post-feeding. Anim. Nutr. 1:329-338. https://doi .org/10.1016/j.aninu.2015.11.009.

Wang, M., R. Wang, T. Xie, P. H. Janssen, X. Sun, K. A. Beauchemin, and Z. Tan., and G. M. 2016b. Shifts in rumen fermentation and microbiota are associated with dissolved ruminal hydrogen concentrations in lactating dairy cows fed different types of carbohydrates. J. Nutr. 146:1714-1721. https://doi.org/10.3945/jn.116 .232462 .

Wang, Q. H., L. J. Yu, Y. Liu, L. Lin, R. G. Lu, J. P. Zhu, L. He, and Z. L. Lu. 2017. Methods for the detection and determination of nitrite and nitrate: A review. Talanta 165:709-720. https://doi .org/10.1016/j.talanta.2016.12.044.

Weatherburn, M. 1967. Phenol-hypochlorite reaction for determination of ammonia. Anal. Chem. 39:971-974. https://doi.org/10 $.1021 /$ ac60252a045.

Weimer, P. J. 1993. Effects of dilution rate and $\mathrm{pH}$ on the ruminal cellulolytic bacterium Fibrobacter succinogenes S85 in cellulose-fed continuous culture. Arch. Microbiol. 160:288-294.

Zhou, Z., Z. Yu, and Q. Meng. 2012. Effects of nitrate on methane production, fermentation, and microbial populations in in vitro ruminal cultures. Bioresour. Technol. 103:173-179. https://doi.org/ 10.1016/j.biortech.2011.10.013.

Zinn, R., and F. Owens. 1986. A rapid procedure for purine measurement and its use for estimating net ruminal protein synthesis. Can. J. Anim. Sci. 66:157-166. https://doi.org/10.4141/cjas86-017. 